\title{
Bacterial Extracellular DNA Promotes $\beta$-Amyloid Aggregation
}

\author{
George Tetz and Victor Tetz *(D) \\ Department of Neuroscience, Human Microbiology Institute, New York, NY 10128, USA; g.tetz@hmi-us.com \\ * Correspondence: georgetets@gmail.com
}

check for

updates

Citation: Tetz, G.; Tetz, V. Bacterial Extracellular DNA Promotes $\beta$-Amyloid Aggregation. Microorganisms 2021, 9, 1301. https://doi.org/10.3390/ microorganisms 9061301

Academic Editor: Mario Clerici

Received: 22 May 2021

Accepted: 11 June 2021

Published: 15 June 2021

Publisher's Note: MDPI stays neutral with regard to jurisdictional claims in published maps and institutional affiliations.

Copyright: (c) 2021 by the authors. Licensee MDPI, Basel, Switzerland. This article is an open access article distributed under the terms and conditions of the Creative Commons Attribution (CC BY) license (https:/ / creativecommons.org/licenses/by/ $4.0 /)$.

\begin{abstract}
Alzheimer's disease is associated with prion-like aggregation of the amyloid $\beta(\mathrm{A} \beta)$ peptide and the subsequent accumulation of misfolded neurotoxic aggregates in the brain. Therefore, it is critical to clearly identify the factors that trigger the cascade of $A \beta$ misfolding and aggregation. Numerous studies have pointed out the association between microorganisms and their virulence factors and Alzheimer's disease; however, their exact mechanisms of action remain unclear. Recently, we discovered a new pathogenic role of bacterial extracellular DNA, triggering the formation of misfolded Tau aggregates. In this study, we investigated the possible role of DNA extracted from different bacterial and eukaryotic cells in triggering $A \beta$ aggregation in vitro. Interestingly, we found that the extracellular DNA of some, but not all, bacteria is an effective trigger of A $\beta$ aggregation. Furthermore, the acceleration of $A \beta$ nucleation and elongation can vary based on the concentration of the bacterial DNA and the bacterial strain from which this DNA had originated. Our findings suggest that bacterial extracellular DNA might play a previously overlooked role in the A $\beta$ protein misfolding associated with Alzheimer's disease pathogenesis. Moreover, it highlights a new mechanism of how distantly localized bacteria can remotely contribute to protein misfolding and diseases associated with this process. These findings might lead to the use of bacterial DNA as a novel therapeutic target for the prevention and treatment of Alzheimer's disease.
\end{abstract}

Keywords: Alzheimer's disease; amyloid-beta; amyloid plaques; bacterial DNA; protein aggregation

\section{Introduction}

The misfolding, aggregation, and accumulation of amyloid-forming proteins are key pathological occurrences in protein misfolding diseases [1] These diseases include systemic amyloidosis, type 2 diabetes, and a broad variety of neurodegenerative diseases, such as Alzheimer's disease (AD), Parkinson's disease, Huntington's disease, amyotrophic lateral sclerosis, and many others [2-5]. AD is the most common cause of dementia worldwide and is a leading cause of death in elderly individuals in the developed world [6]. The disease is characterized by a progressive cognitive decline and amnestic impairment. This is due to specific neuropathological changes in the brain as a result of the formation and accumulation of neurotoxic extracellular amyloid plaques and intracellular neurofibrillary tangles $[7,8]$. The formation and deposition of amyloid plaques appear to be among the earliest and most significant pathological events in AD [9]. These amyloid plaques are composed of aggregated amyloid- $\beta$ protein $(A \beta)$, which is a 42-residue peptide formed from the enzymatic processing of the amyloid precursor protein [10-13]. A seeding nucleation prion-like mechanism is responsible for a conformational switch in the $A \beta$ protein, which results in the misfolding, selfpropagation, and fibrillar aggregation of $A \beta$, which becomes deposited in the brain parenchyma in the form of neuritic amyloid plaques [1]. However, despite decades of research, the mechanisms and factors responsible for the initiation of $A \beta$ misfolding remain elusive $[14,15]$.

It is believed that the interaction between genetic and environmental factors contributes to AD development $[16,17]$. Many proteins and non-protein components have been shown to promote or inhibit $\mathrm{A} \beta$ misfolding and aggregation in vitro and in vivo; 
however, whether they are involved in the AD process remains unclear $[18,19]$. The lack of a clear understanding of the factors that trigger the cascade of AD might in part be responsible for the numerous failures of anti-AD drugs in clinical trials that have occurred in recent years [20].

Recently, an increasing number of studies have implicated microorganisms and viruses as culprits in $\mathrm{AD}$ and other neurodegenerative diseases [21-26]. At the same time, their exact mechanisms through which they trigger $\mathrm{AD}$ remain unclear. The dominant theory is that changes in microbiota can induce neuroinflammation or alter metabolic, endocrinal, and immunological pathways [18]. The involvement of microorganisms is believed to occur both directly, via their migration to the brain followed by the activation of host microglia and peripheral immune cells [27], or indirectly, through regulation of the microbiota-gutbrain axis and the passage of bacterial components and virulence factors from the impaired blood-brain barrier to the CNS [28-31].

We have recently shown another possible universal pathway by which microorganisms might trigger diseases associated with protein misfolding. We discovered that bacterial extracellular DNA (eDNA) leads to the modification of already synthesized proteins that are converted into altered heat-resistant Tetz-proteins or they aggregate into cross- $\beta$ structures $[32,33]$. We found that the DNA released from bacteria associated with Parkinson's disease, type 1 diabetes, and AD can trigger $\alpha$-synuclein, islet amyloid polypeptide, and tau misfolding, thus implicating it as a potential virulence factor in these pathologies [33-35]. These data are aligned with our previous findings, showing that the deoxyribonuclease I enzyme that cleaves extracellular DNA might have some benefit for patients with AD [36].

To test whether DNA triggers A $\beta$ misfolding, we used eDNA from bacterial species known to be associated with AD, as well as human DNA. We used DNA from the oral bacteria Porphyromonas gingivalis, Tetzerela hominis, Escherichia coli, and Borrelia burgdorferi, which has been detected in the cerebrospinal fluid (CSF) and postmortem brains of individuals with $\mathrm{AD}$ or have been suggested to be AD-discriminative microorganisms [27,37-39]. We hypothesized that eDNA from these representative oral microbiota might be specifically implicated in AD development through the mouth-brain axis. Indeed, DNA of oral bacteria can reach the CNS, not only through the typical means of the weakened bloodbrain barrier $[18,40]$, but also through direct release by these microorganisms into the brain following their invasion of the CNS due to neurotropism and spread through cranial nerves $[27,41-43]$. In this study, using an in vitro $A \beta$ aggregation assay, we observed that eDNA of some bacteria could induce $A \beta$ misfolding and aggregation.

\section{Materials and Methods}

\subsection{Sources and Procedures for DNA Extraction}

Extracellular DNA was extracted from the matrix of Escherichia coli ATCC25922, E. coli ATCC 472217, E. coli G39, E. coli dPHF, E. coli MUP6, Porphyromonas gingivalis ATCC BAA308, Burkholderia burgdorferi ATCC35210, and Tetzosporium hominimis VT-49. All bacterial strains were subcultured from freezer stocks onto Columbia agar plates (Oxoid, Hampshire, UK) and were incubated at $37^{\circ} \mathrm{C}$ for $48 \mathrm{~h}$. Human genomic DNA $(0.2 \mathrm{~g} / \mathrm{L}$ in $10 \mathrm{mM}$ tris- $\mathrm{HCl}$, 1 mM EDTA, pH 8.0, Cat. No. 11691112001) was purchased from Sigma (Sigma-Aldrich, St Louis, MO, USA) and consisted of high molecular weight (>50,000 bp) genomic DNA isolated from human blood.

\subsection{DNA Fragment Size Characterization with an Agilent Bioanalyzer}

The sizes of DNA from different E. coli strains were analyzed using an Agilent Bioanalyzer 2100 instrument (Agilent Technologies, Santa Clara, CA, USA) following the manufacturer's recommended protocol using Agilent 2100 Expert software.

\subsection{DNA and RNA Extraction and Purification}

To isolate extracellular nucleic acids, the cell suspension was centrifuged and separated from the extracellular matrix by washing twice in phosphate-buffered saline (PBS; $\mathrm{pH}$ 7.2; 
Sigma, St Louis, MO, USA) and centrifuged at $4000 \times g$ for 15 min (Microfuge 20R, Beckman Coulter, Brea, CA, USA) followed by resuspension in PBS. Next, the supernatant was filtered through a $0.22 \mu \mathrm{M}$ filter to remove any bacterial cells. Extracellular DNA was extracted using a DNeasy Blood \& Tissue Kit (Qiagen, Hilden, Germany) according to the manufacturer's instructions. Purified DNA quality was assessed using a NanoDrop OneC spectrophotometer (Thermo Fisher Scientific, Waltham, MA, USA). Samples with a DNA OD $260 / 280=1.8-2.0$ were used for further analysis.

Extracellular or total intracellular RNA was purified using the RNeasy Mini Kit (Qiagen) according to the manufacturer's recommended protocol. The evaluation of RNA quantity and quality was performed spectrophotometrically based on UV absorbance at 230/260/280 nm with a NanoDrop OneC spectrophotometer (Thermo Fisher Scientific, Waltham, MA, USA). Some of the DNA probes were treated with 100 units of DNase I (Sigma-Aldrich, St Louis, MO, USA) for $20 \mathrm{~min}$ at $37^{\circ} \mathrm{C}$ to degrade DNA in the probes.

\subsection{A $\beta$ Synthesis and Preparation}

A $\beta 1-42$ peptide was produced by solid-phase synthesis at The ERI Amyloid Laboratory, LLC, and purified ( $>95 \%$ purity) by reverse-phase chromatography. Peptides were dissolved in 50\% acetonitrile, frozen, and lyophilized overnight. Lyophilized A $\beta$ was dissolved in $10 \mathrm{mM} \mathrm{NaOH}$ ( $\mathrm{pH}$ 12). The material was centrifuged in a $30 \mathrm{kDa}$ cut-off filter for $12 \mathrm{~min}$ at $14,000 \times g$ at $4{ }^{\circ} \mathrm{C}$ to obtain the "seed-free" solution.

\subsection{In Vitro Aggregation Assay and Half-Time Analysis}

$\mathrm{A} \beta$ seed-free solution was diluted to a final concentration of $6 \mu \mathrm{M}$ in $50 \mathrm{mM}$ tris- $\mathrm{HCl}$ and incubated with intermittent shaking $(450 \mathrm{rpm})$ at $15^{\circ} \mathrm{C}$. DNA probes were added in water, and the same volume of water was used as negative controls. Then, $5 \mu \mathrm{M}$ thioflavin $\mathrm{T}$ (ThT) was added so that aggregation over time could be measured by fluorescence at $485 \mathrm{~nm}$ after $435 \mathrm{~nm}$ excitation. The maximum fluorescence intensity of a sample was used to calculate the normalized intensity for presentation purposes. Thus, we normalized ThT fluorescence taken at each timepoint to $100 \%$ of the maximum value. To quantify the kinetics of $A \beta$ aggregation, we determined the half-time (t1/2), at which normalized ThT fluorescence reaches half the maximum intensity [44].

\subsection{Statistical Analysis}

The significance of the differences in aggregation kinetics of $A \beta$ in the presence of different DNA samples was analyzed by one-way ANOVA, followed by Tukey's multiple comparison post-test. To compare the effect of different DNA samples, we estimated alterations of ThT fluorescence and the $t 1 / 2$, which corresponds to the time at which $50 \%$ aggregation is obtained. The level of significance was set at $p<0.05$.

\section{Results}

Effect of DNA from Different Organisms on A $\beta 1-42$ Aggregation Kinetics

To investigate the effect of DNA on A $\beta$ misfolding and aggregation, we studied the fibrillation kinetics of $A \beta$ in the absence or the presence of extracellular DNA extracted from different bacterial species that were previously shown to be associated with AD, as well as human cells [27,37-39]. As it is well known that the onset of A $\beta$ aggregation varies significantly within different experiments and replicates of the same sample, all experiments were performed at the same time with the same reagents, and ThT fluorescence curves were normalized. First, we found that DNA of different organisms taken at a fixed concentration of $1000 \mathrm{ng} / \mathrm{mL}$ affected $\mathrm{A} \beta$ aggregation differently. The maximum fluorescence value was considerably higher only following the addition of DNA from E. coli ATCC 25922 (Figure 1A). No significant effect on maximum ThT fluorescence was detectable after the addition of eDNA from $P$. gingivalis ATCC BAA-308, B. burgdorferi ATCC 35210, or T. hominimis VT-49 gen. nov, sp. nov, a new species isolated from the oral cavity of a patient with AD, as well as human DNA. 


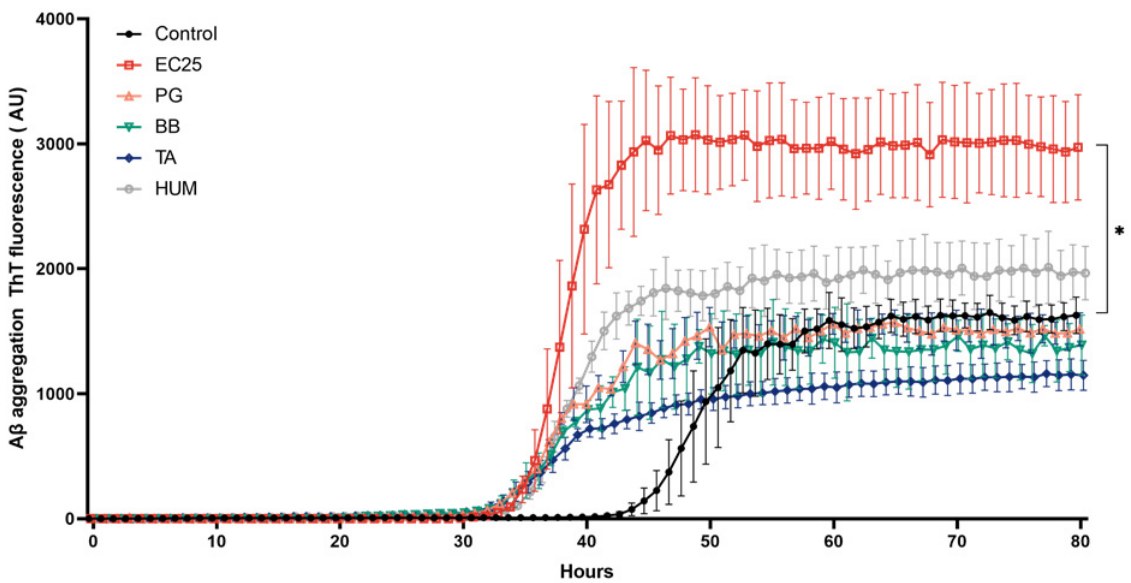

(A)

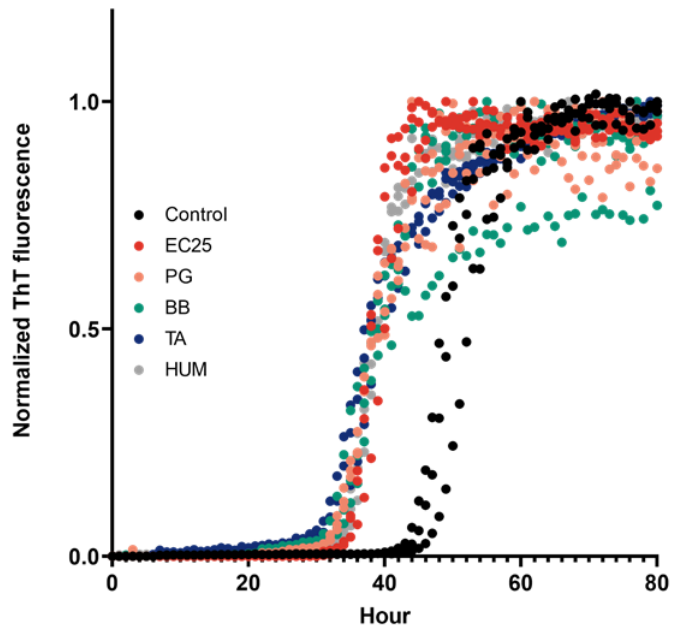

(B)

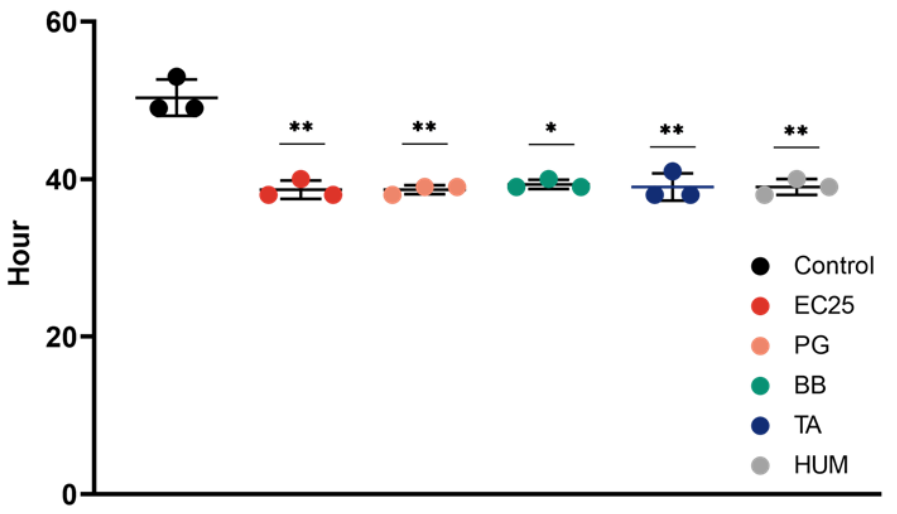

(C)

Figure 1. Effects of bacterial and human DNA on amyloid $\beta(A \beta)$ aggregation. ThT fluorescence assay was used to monitor the aggregation of $\mathrm{A} \beta(1-42)$ at $6 \mu \mathrm{M}$ in $50 \mathrm{mM}$ tris- $\mathrm{HCl}$ in the presence and absence of bacterial DNA of E. coli ATCC25922 (EC25), P. gingivalis (PG), Borrelia burgdorferi (BB), T. alzheimeri (TA), or human DNA (HUM) at $1000 \mathrm{ng} / \mathrm{mL}$. (A) ThT fluorescence as a function of time (h), (B) normalized ThT fluorescence as a function of time, (C) and the corresponding t1/2 values. Each experiment was performed in triplicate. For images $(\mathbf{A})$ and $(\mathbf{C})$, data are presented as mean $\pm \mathrm{SD}^{*} p \leq 0.05^{* *} p \leq 0.01$; for $(\mathbf{B})$, the individual traces from three replicates are shown. 
To allow for an easier visual comparison of the kinetics of protein aggregation, we normalized fibrillation curves (Figure 1B). It was clearly seen that in both control and DNAtreated probes, $A \beta$ (1-42) aggregation exhibits a characteristic sigmoidal curve indicative of amyloid formation via primary nucleation. We observed shortening of the lag phase, defined as the time at which aggregation begins following the addition of all DNA samples used [44]. A $\beta$ seeded with bacterial or human DNA showed a lag phase of approximately $10 \mathrm{~h}$ before that of the untreated control probe group $(p<0.05)$. As expected, we also found a reduction in the $t 1 / 2$ values of the amyloid growth phase after the addition of any DNA probes (Figure 1C).

As the eDNA of E. coli ATCC25922 was shown to be the only DNA sample to trigger higher ThT fluorescence values, we next tested the effect of eDNA from different $E$. coli strains on this process (Figure 2A). Along with two ATCC strains, E. coli ATCC25922 and E. coli ATCC472217, we used three E. coli clinical isolates, G39, dPHF, and MUP6, which were isolated from the oral cavity of patients with advanced AD. Upon addition of eDNA of different $E$. coli strains, we found that the ThT signal was only increased by the eDNA of E. coli ATCC25922 $(p<0.01)$. It was slightly inhibited by eDNA of E. coli ATCC 472217 and was mostly unaffected by the addition of eDNA from other E. coli (Figure 2A). At the same time, we found that eDNA of all E. coli strains except E. coli ATCC 472217 significantly shortened the lag-phase and corresponding t1/2 values (Figure $2 \mathrm{~A}, \mathrm{~B}$ ).

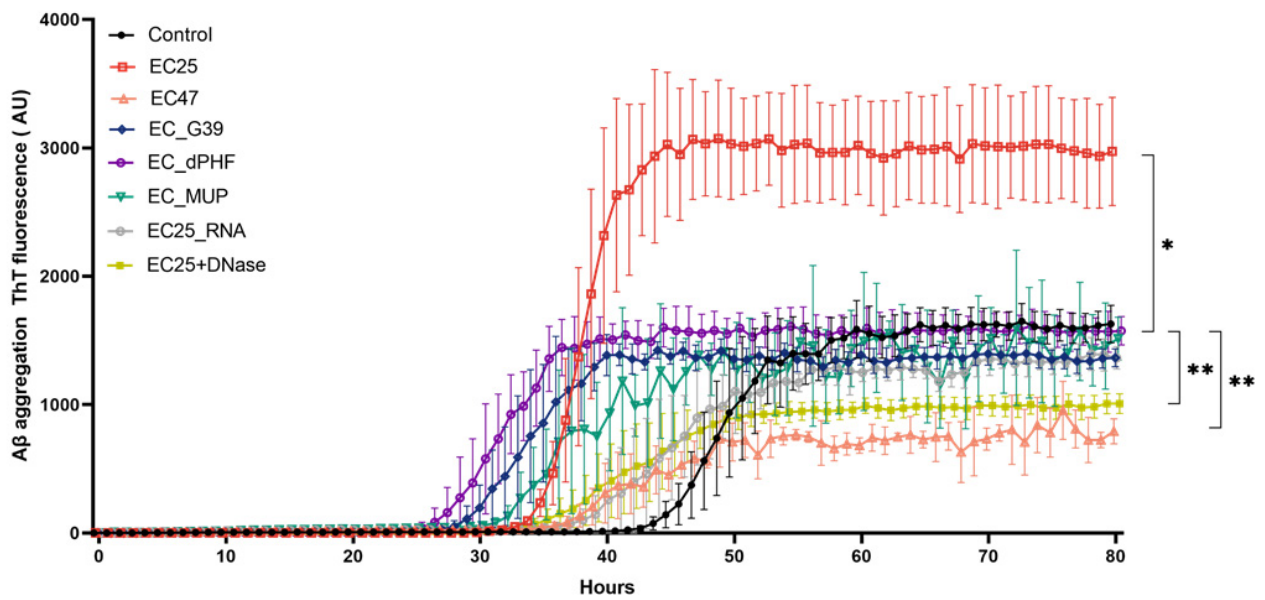

(A)

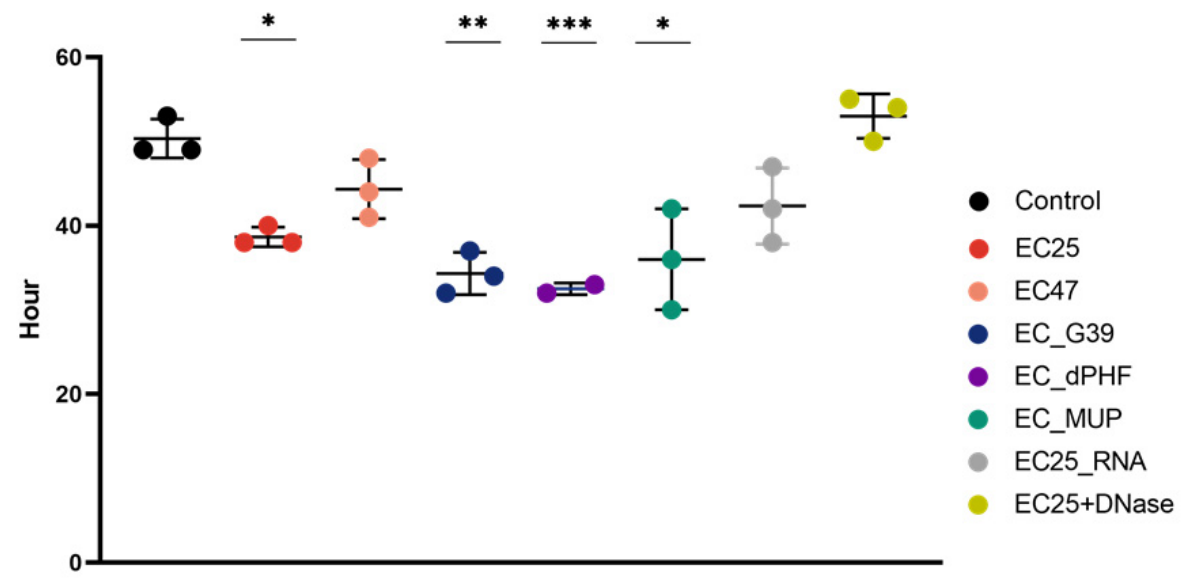

(B)

Figure 2. Cont. 


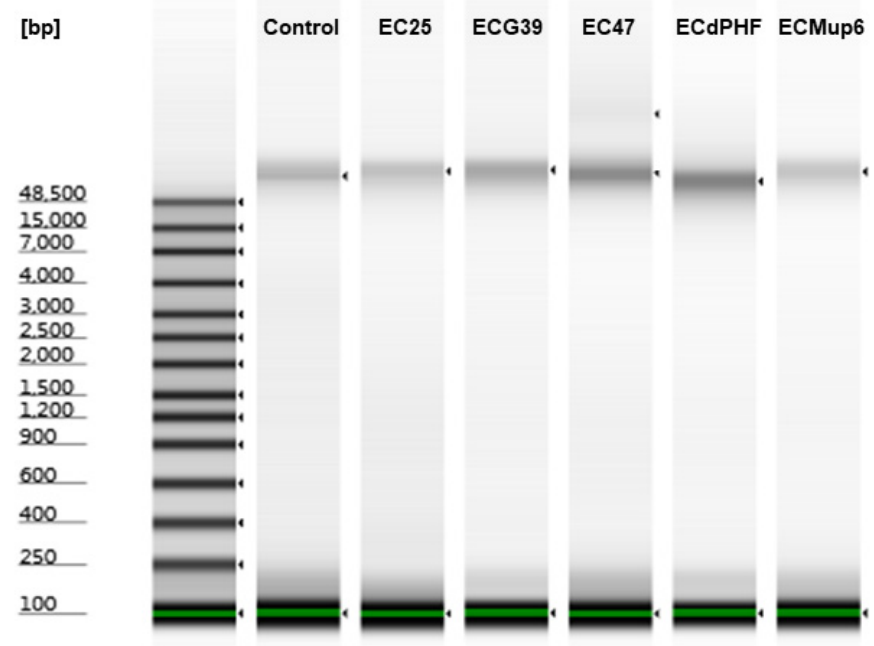

(C)

Figure 2. Effect of eDNA and RNA of different Escherichia coli strains on amyloid $\beta(A \beta)$ aggregation. To study the effect of DNA on $A \beta$ aggregation, $A \beta 1-42$ oligomers were incubated with preparations containing $1000 \mathrm{ng}$ of nucleic acids extracted from different strains of E. coli. eDNA of E. coli ATCC29522 (EC25), E. coli ATCC472217 (EC47), E. coli G39 (ECG39), E. coli dPHF (ECdPHF), and E. coli MUP6 (ECMup6), RNA of E. coli ATCC29522 (EC25_RNA), and eDNA of E. coli ATCC29522 treated with DNase (EC25+DNase) were used. (A). ThT fluorescence as a function of time in the presence of indicated DNA and RNA probes (h); (B) t1/2 values of aggregation. Values represent the mean $\pm \mathrm{SD}$ of experiments performed in triplicate. ${ }^{* *} p \leq 0.001{ }^{* *} p \leq 0.01{ }^{*} p \leq 0.05$. (C) Bioanalyzer gel image for eDNA extracted from different strains of $E$. coli.

Surprisingly, we observed aggregation curves with the shortest lag phase and the most decreased $\mathrm{t} 1 / 2$ following the adding of DNA of E. coli dPHF-; however, it did not increase ThT fluorescence.

As expected, the destruction of eDNA from E. coli ATCC25922 by DNase I and its subsequent addition to $A \beta(1-42)$ completely inhibited the increase in ThT fluorescence and decrease in the $t 1 / 2$, which were observed for the undigested $t 1 / 2$ (Figure 2A,B). This is related to the specificity of the eDNA and not to the effect of the seeding of beta-amyloid misfolding by nucleotides. We also determined that RNA from E. coli ATCC25922 had not increased ThT fluorescence or accelerated the kinetics of $\mathrm{t} 1 / 2$ for $\mathrm{A} \beta$ aggregation (Figure 2B).

To explain this difference in the aggregation potential of various $E$. coli DNA samples, we analyzed eDNA sizes using an Agilent Bioanalyzer (Figure 2C). Surprisingly, the analyses showed no visible differences between eDNA from different $E$. coli strains consisting of fragments of approximately $50 \mathrm{~kb}$ with identical amounts of lower molecular weight DNA. The dependence of $A \beta$ ThT fluorescence on the bacterial DNA concentration was then examined using eDNA from E. coli and P. gingivalis by a ThT assay (Figure 3A,B). eDNA of E. coli ATCC 25922 added in concentrations varying from 0.1 to $10,000 \mathrm{ng} / \mathrm{mL}$ differentially affected A $\beta$ fibrillation. The highest concentration of eDNA from E. coli ATCC25922 at $10,000 \mathrm{ng} / \mathrm{mL}$ did not increase ThT fluorescence, whereas lower concentrations of DNA from 0.1 to $1000 \mathrm{ng} / \mathrm{mL}$ had a clear dose-dependent effect on $\mathrm{A} \beta$ aggregation, with the most pronounced increase in ThT fluorescence of over 2.9-fold following treatment with $1000 \mathrm{ng} / \mathrm{mL}$ DNA (Figure 3A). 


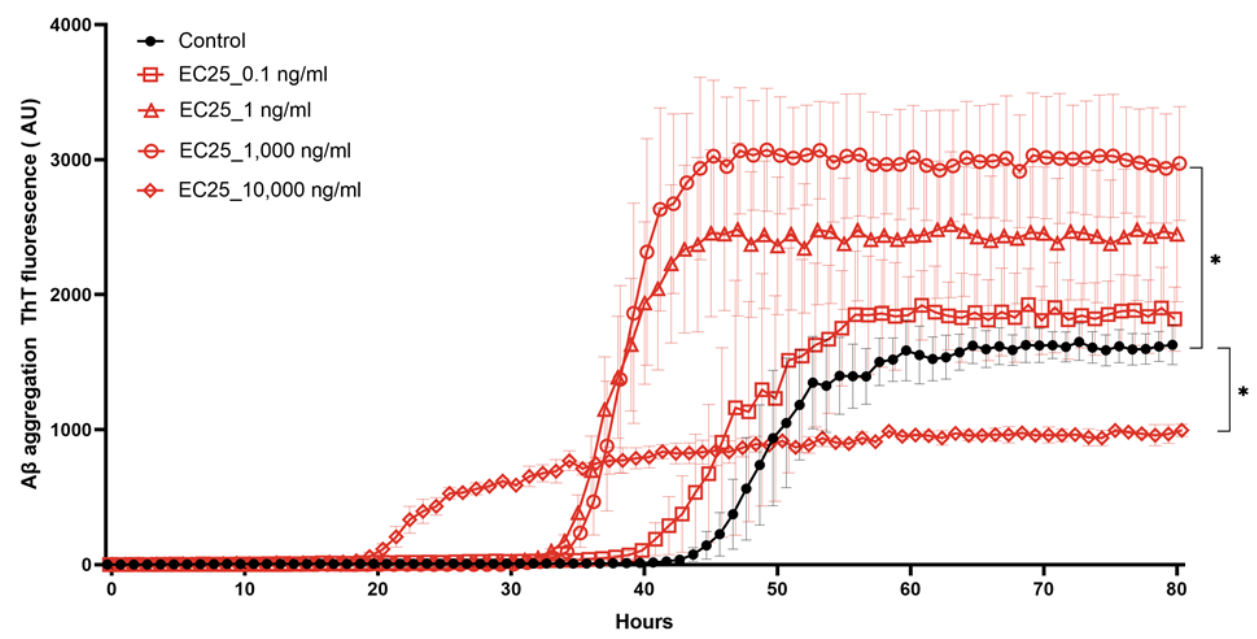

(A)

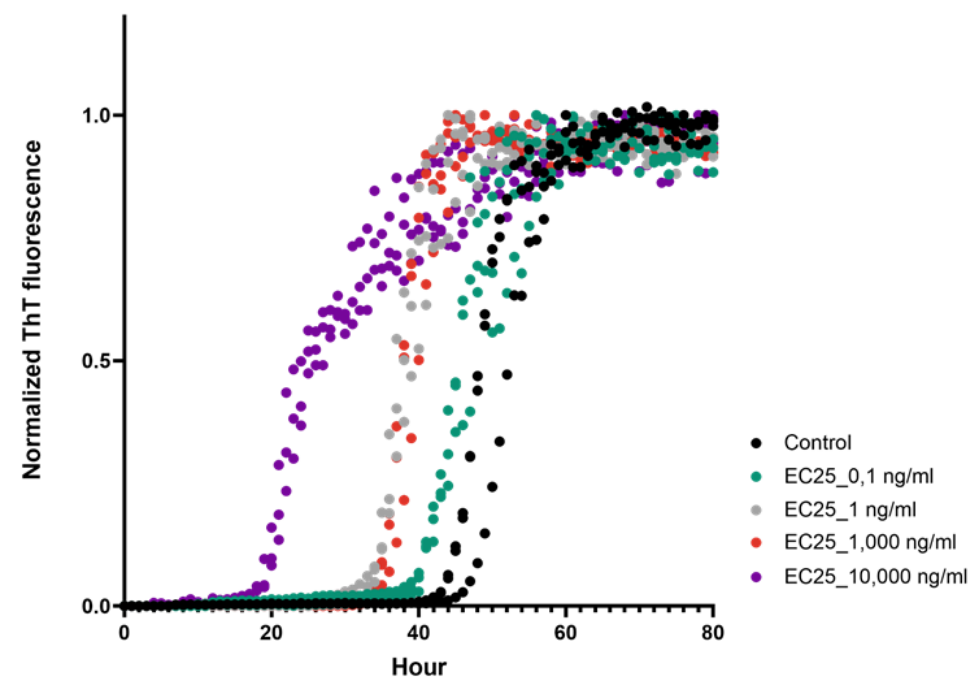

(B)

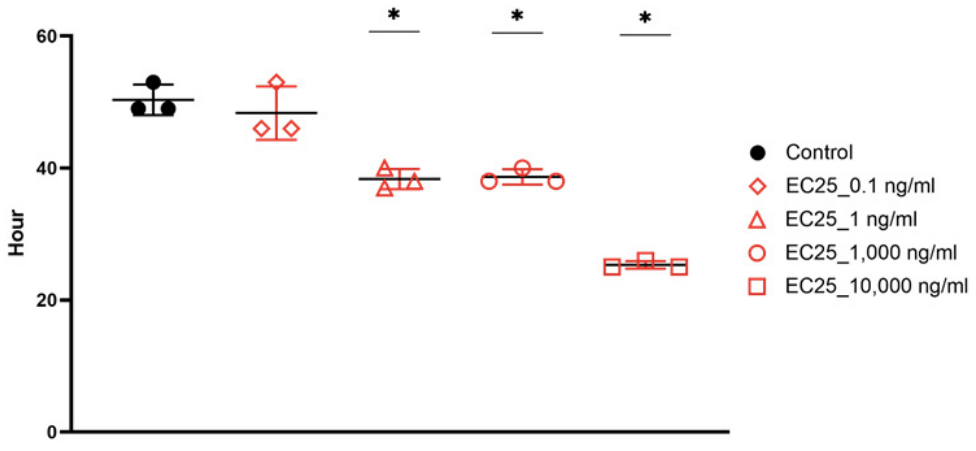

(C)

Figure 3. Cont. 


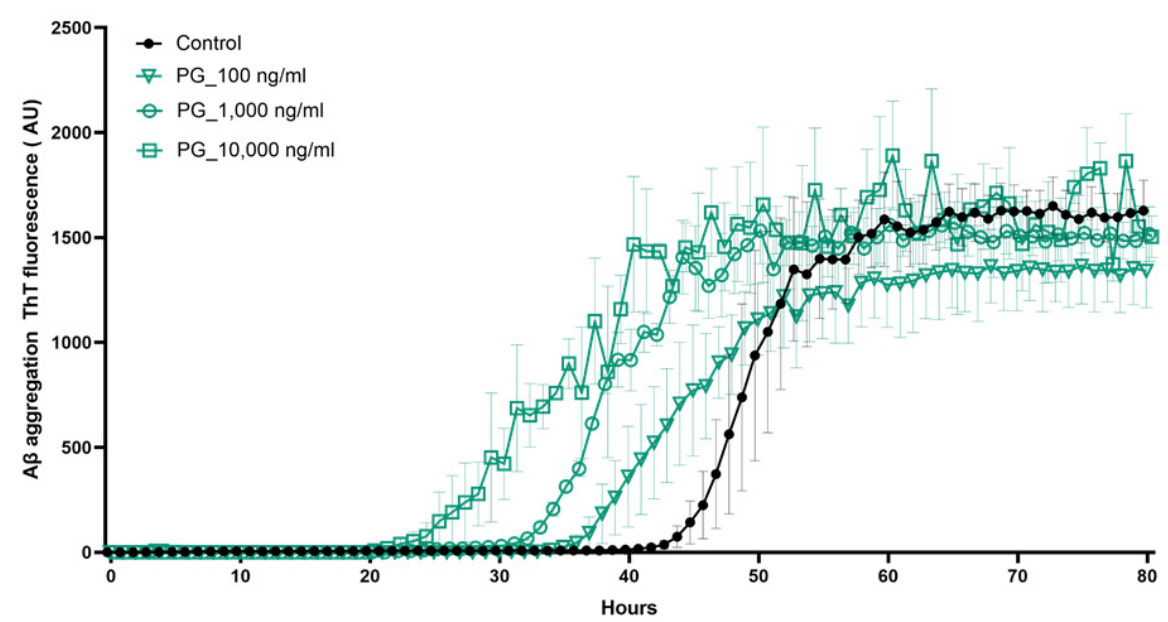

(D)

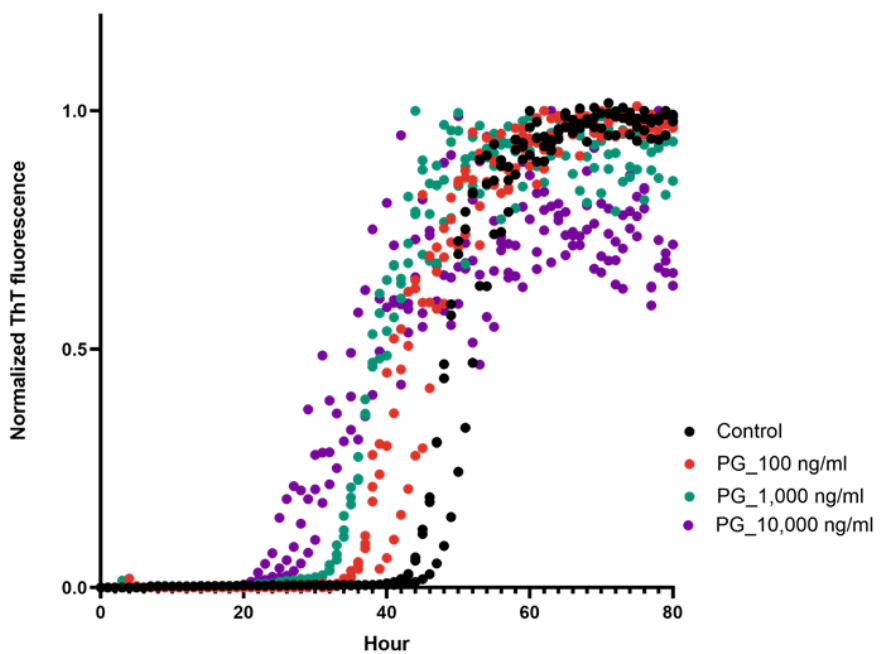

(E)

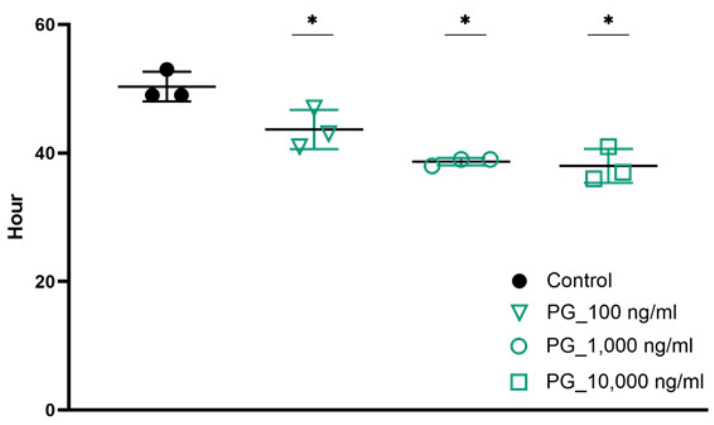

(F)

Figure 3. Dose-dependent effect of eDNA on amyloid $\beta(\mathrm{A} \beta)$ aggregation. Dose-dependent effect of DNA from Escherichia coli ATCC29522 and Porphyromonas gingivalis on A $\beta$ aggregation. Effect of the eDNA of E. coli ATCC29522 on (A) the aggregation of ThT fluorescence as a function of time, (B) normalized ThT fluorescence (relative aggregate concentration) as a function of time (h), and (C) $\mathrm{t} 1 / 2$ values of the aggregation. Effect of the eDNA of $P$. gingivalis on (D) the aggregation of ThT fluorescence as a function of time, (E) normalized ThT fluorescence (relative aggregate concentration) as a function of time (h), and (F) t1/2 values of aggregation. For the images $(\mathbf{A}, \mathbf{C}, \mathbf{D}, \mathbf{F})$ symbols represent averages and error bars represent the standard deviation of experiments performed in triplicate. ${ }^{*} p \leq 0.05$; For the images $(\mathbf{B}, \mathbf{E})$ all replicates from three experiments are shown in the plot. 
By measuring lag-phase and $t 1 / 2$, we observed that the tested concentrations of eDNA in E. coli ATCC25922 had a dose-dependent effect. The highest acceleration of A $\beta$ aggregation was reflected in the shortening of the lag-phase and decrease in the T1/2 found after the addition of the DNA at 10,000 ng/mL (Figure 3B,C). There were fewer pronounced alterations in these parameters after the addition of DNA taken at lower concentrations. eDNA from $P$. gingivalis did not increase ThT fluorescence at any concentration from 100 to $10,000 \mathrm{ng} / \mathrm{mL} \mathrm{ng} / \mathrm{mL}$. However, eDNA from $P$. gingivalis resulted in a dose-dependent reduction in the lag-phase and $t 1 / 2$, highlighting its effect on nucleation enhancement, but not on $\mathrm{A} \beta$ elongation (Figure 3D-F) $[45,46]$.

\section{Discussion}

The formation and deposition of neurotoxic $A \beta$ aggregates within the brain of patients with $\mathrm{AD}$ is a critical pathogenic pathway that causes cognitive decline. Although the molecular basis for $A \beta$ aggregation has been extensively studied, and accumulating evidence supports the notion that a prion-like mechanism is responsible for this process, until now, the exact factor responsible for triggering seeded nucleation remained elusive $[14,47]$. The suspicion that the seeding factor of AD might arise from microorganisms has been advanced by many groups $[48,49]$. However, the identity of the microbial component that might trigger prionogenic transformation was unclear.

In our previous studies, we showed that eDNA from different bacterial species can act as a virulence factor and modify a variety of proteins in different ways, including the prion-like templated aggregation of Tau proteins, highlighting the role of bacterial DNA in "genetic information metabolism" $[32,33,50]$. In this study, we investigated bacterial eDNA from various Gram-positive and Gram-negative bacteria including oral pathogens associated with $\mathrm{AD}$ development, which might trigger $\mathrm{A} \beta$ misfolding. It is important to highlight that eDNA of these oral pathogens reaches the CNS via multiple ways. In addition to the general mechanism used by non-oral localized microorganisms to reach the brain from the blood stream through an altered blood-brain barrier, some oral bacteria can invade the brain through cranial nerves (e.g., olfactory or trigeminal nerves) and affect the brain more directly [51,52]. The invasion of the brain by bacteria enables the direct secretion of their extracellular DNA or release under certain conditions, such as prophage activation $[35,53]$. This results in the release of bacterial DNA directly into the CNS, leading to a high local DNA concentration.

Using the amyloid-specific fluorescent dye thioflavin-T, for which fluorescence increases in intensity as amyloid beta fibrils aggregate, we found that eDNA from all bacteria studied similarly accelerated the kinetics of $A \beta$ aggregation. This was reflected in the shortened lag-phase and decreased $\mathrm{t} 1 / 2$. However, only eDNA of E. coli ATCC 25922 resulted in an increase in maximum ThT fluorescence, whereas the eDNA of other bacteria did not alter this parameter.

The monitoring of eDNA from different E. coli strains surprisingly showed that the catalysis of $A \beta$ aggregation has DNA strain-specific characteristics. Thus, only the eDNA from some of the E. coli strains shortened the lag phase, whereas others did not affect it. Moreover, among the E. coli eDNA samples that did increase nucleation and shorten the lag-phase, only the eDNA of E. coli ATCC25922 potentiated elongation and increased ThT fluorescence intensity at the plateau [54,55]. We suggested that the cause for such a difference in ThT fluorescence could be related to the efficacy of triggering $A \beta$ aggregation and the differences in the sizes of eDNA molecules. Intriguingly, analysis of eDNA molecule size from different $E$. coli strains revealed no association between the eDNA band size of an E.coli strain and its effect on $A \beta$ aggregation. When viewed in light of our previous data, these results reveal the same lack of a correlation between bacterial DNA size and its effects on tau misfolding [33]. This suggests that the aggregation capacity of eDNA molecules is not only directly relevant to their length.

At the same time, it is necessary to highlight that DNA is a polyanionic molecule [56]. Moreover, previous studies have shown that the acceleration of fibril formation and protein 
misfolding can be triggered by polymers and specifically depends on the polyanionic characteristics of such a molecule [57]. For example, glycosaminoglycans, due to their polyanionic nature and the presence of certain binding sites, function as scaffolds in triggering and enhancing the aggregation of peptide molecules, favoring a $\beta$-sheet conformation [58]. Therefore, higher ThT fluorescence following seeding mediated by eDNA of E. coli ATCC 25922 might occur through the existence of specific binding sites along the polymer compared with eDNA of other E. coli strains even though have the same sizes; however, we would like to emphasize that studying the reasons why DNA triggers A $\beta$ aggregation was not the goal of this study [59].

To study the dose dependence of eDNA of E. coli and P. gingivalis on A $\beta$ aggregation, we used a wide range of concentrations, starting from 0.1 to $10,000 \mathrm{ng} / \mathrm{mL}$. There are no data on the concentration of bacterial DNA in the brain tissue of CSF of patients with AD. Thus, the concentration of bacterial DNA used was approximated based on the range of CSF DNA concentrations, from $1 \mathrm{ng} / \mathrm{mL}$ to $600 \mathrm{ng} / \mathrm{mL}$, observed in patients with different diseases [60-62].

The addition of E. coli ATCC25922 eDNA affected A $\beta$ aggregation in a nonlinear fashion because the highest concentrations of DNA $(10,000 \mathrm{ng} / \mathrm{mL})$ decreased ThT fluorescence, whereas exposure to lower concentrations of DNA increased it. The reason for such a discrepancy has not been determined, particularly considering that under the same conditions, eDNA from E. coli ATCC25922 from 0.1 to $10,000 \mathrm{ng} / \mathrm{mL}$ potentiated nucleation in a linear fashion with a dose-dependent acceleration of $t 1 / 2$. The unconventional aggregation kinetics observed with $10,000 \mathrm{ng} / \mathrm{mL}$ of $E$. coli eDNA could be explained by the fact that DNA at such a high concentration triggers the formation of intermediates that might lead to off-pathway effects on mature fibril formation [63]. Since the level of ThT florescence intensity reflects mature fibrils as they bind to $\beta$-sheet-rich structures, the formation of $\beta$-sheet-poor aggregates during the elongation phase following the addition of $E$. coli $\mathrm{eDNA}$ at 10,000 $\mathrm{ng} / \mathrm{mL}$ might explain the lower ThT fluorescence, along with faster kinetics $[44,55,64,65]$. The ability of bacterial DNA to trigger the appearance of intermediate oligomeric species and off-pathway end products is particularly interesting since the presence of these species and products is a more important risk factor for the development of amyloid diseases compared to mature fibrils [63]. Thus, the differential effects of eDNA on protein misfolding, which depends on both the amount of eDNA and type of bacteria from which this eDNA is released, may overlap with recent discoveries of the existence of structurally distinct $A \beta$ polymorphs (strains) that contribute to the variety of clinical phenotypes of AD [66-68]. Therefore, in the follow-up studies it would be critical to conduct an electronic or atomic force microscopy analysis to examine the effects of eDNA-induced $\beta$-amyloid aggregates on the pathogenesis of $\mathrm{AD}$, and to analyze whether eDNA from different bacterial species in different amounts can induce the formation of different strains of prions.

Notably human DNA was not found to increase the ThT fluorescence of $A \beta$, as in our previous study when it had no effect on Tau aggregation [33]. However, we are planning to investigate whether other types of human DNA, such as neutrophil extracellular traps known for their distinctive features compared with other DNA types, have different effects on $A \beta$ fibrillation and are going to test this in follow-up studies [69]. Our observation that eDNA from different $E$. coli strains differently affected $A \beta$, meaning that not all bacterial DNA possesses equal $A \beta$ prionogenic activity, might address the question of why some people with signs of bacterial presence in the brain develop AD and some do not [70]. Indeed, many papers describe the presence of bacteria or their components in CSF and postmortem brains not only of individuals with $\mathrm{AD}$, but also in samples of matched controls $[18,41,71]$. This raises the unanswered question of why some people who have bacteria or Pathogen-Associated Molecular Pattern (PAMPs) present in their CNS develop neurodegeneration and some do not, since the presence of even a small amount of bacterial PAMPs activates microglia and astrocytes, and considering bacterial eDNA as a strainspecific triggering factor of $A \beta$ aggregation might explain this discrepancy [24,72-75]. 
These observations raise an intriguing question that has to be addressed in the follow-up studies: could harboring of some E. coli and P. gingivalis strains, even in asymptomatic patients with no oral or gastrointestinal diseases, be a potential risk factor for AD.

Moreover, our data outline a new potential mechanism through which distantly localized bacteria, including those localized in the gut, exert effects via the secretion and release of eDNA, which can pass through the blood-brain barrier and could remotely contribute to AD development and aggravate its progression. Our findings are in accordance with the dual-hit hypothesis, which states that the pathological aggregation of prions starts in the enteric nervous system (ENS), which retrogradely spreads via the vagus nerve to the brain [76-80]. Hence, the presence of certain bacterial strains in the gut, in which eDNA can promote protein propagation, should be further studied.

These observations raise the intriguing question of whether bacterial DNA could contribute to the pathogenesis of $\mathrm{AD}$; however, many more future studies are required. Thus, elucidating the precise structural differences in different eDNA types such as the CG/AT ratio, DNA forms, minimal length of DNA to accelerate fibrillation, and time and concentration dependence, as well as experiments showing changes in fibril structure and aggregation using the DNA of strains isolated from the CNS and post-mortem brains of patients with $\mathrm{AD}$ are critical for future studies. Overall, our data add another line of evidence that bacterial eDNA as a virulence factor might have additional pathogenic mechanisms through protein aggregation, which could lead to the future translational potential of this discovery.

Author Contributions: G.T. and V.T. designed the experiments. G.T. performed the experiments and supervised data analysis. V.T. and G.T. analyzed the data and wrote the manuscript. All authors have read and agreed to the published version of the manuscript.

Funding: This research received no external funding.

Institutional Review Board Statement: Not Applicable.

Informed Consent Statement: Not applicable.

Data Availability Statement: Not applicable.

Acknowledgments: This research received no specific grant from any funding agency in the public, commercial, or not-for-profit sectors.

Conflicts of Interest: Nothing to declare.

\section{References}

1. Soto, C.; Pritzkow, S. Protein misfolding, aggregation, and conformational strains in neurodegenerative diseases. Nat. Neurosci. 2018, 10, 1332-1340. [CrossRef]

2. Aguzzi, A.; O'connor, T. Protein aggregation diseases: Pathogenicity and therapeutic perspectives. Nat. Rev. Drug Discov. 2010, 9, 237-248. [CrossRef]

3. Kerman, A. Amyotrophic lateral sclerosis is a non-amyloid disease in which extensive misfolding of SOD1 is unique to the familial form. Acta Neuropathol. 2010, 1, 335-344. [CrossRef] [PubMed]

4. Mukherjee, A.; Soto, C. Prion-like protein aggregates and type 2 diabetes. Cold Spring Harb. Perspect. Med. 2017,7 , a024315. [CrossRef] [PubMed]

5. McAlary, L.; Plotkin, S.S.; Yerbury, J.J.; Cashman, N.R. Prion-like propagation of protein misfolding and aggregation in amyotrophic lateral sclerosis. Front. Mol. Neurosci. 2019, 12, 262. [CrossRef] [PubMed]

6. Du, X.; Wang, X.; Geng, M. Alzheimer's disease hypothesis and related therapies. Trans. Neurodegen. 2018, 7, 1-7. [CrossRef]

7. Gamblin, T.C. Caspase cleavage of tau: Linking amyloid and neurofibrillary tangles in Alzheimer's disease. Proc. Nat. Acad. Sci. USA 2003, 100, 10032-10037. [CrossRef]

8. Sakono, M.; Zako, T. Amyloid oligomers: Formation and toxicity of A $\beta$ oligomers. FEBS J. 2010, 277, 1348-1358. [CrossRef] [PubMed]

9. Lorenzo, A. Amyloid $\beta$ interacts with the amyloid precursor protein: A potential toxic mechanism in Alzheimer's disease. Nat. Neurosci. 2000, 3, 460-464. [CrossRef]

10. Du Yan, S. An intracellular protein that binds amyloid- $\beta$ peptide and mediates neurotoxicity in Alzheimer's disease. Nature 1997, 389, 689-695. [CrossRef]

11. Walsh, D.M. Naturally secreted oligomers of amyloid $\beta$ protein potently inhibit hippocampal long-term potentiation in vivo. Nature 2002, 416, 535-539. [CrossRef] [PubMed] 
12. Soto, C. Transmissible proteins: Expanding the prion heresy. Cell 2012, 149, 968-977. [CrossRef] [PubMed]

13. Jucker, M.; Walker, L.C. Self-propagation of pathogenic protein aggregates in neurodegenerative diseases. Nature 2013, 501, 45-51. [CrossRef] [PubMed]

14. Zhang, X.; Fu, Z.; Meng, L.; He, M.; Zhang, Z. The early events that initiate $\beta$-amyloid aggregation in Alzheimer's disease. Front. Aging Neurosci. 2018, 10, 359. [CrossRef]

15. Friesen, M.; Meyer-Luehmann, M. A $\beta$ seeding as a tool to study cerebral amyloidosis and associated pathology. Front. Mol. Neurosci. 2019, 12, 233. [CrossRef]

16. Grant, W.B.; Campbell, A.; Itzhaki, R.F.; Savory, J. The significance of environmental factors in the etiology of Alzheimer's disease. J. Alzheim. Dis. 2002, 4, 179-189. [CrossRef]

17. Heneka, M.T. Neuroinflammation in Alzheimer's disease. Lancet Neurol. 2015, 14, 388-405. [CrossRef]

18. Zhan, X.; Stamova, B.; Sharp, F. Lipopolysaccharide Associates with Amyloid Plaques, Neurons and Oligodendrocytes in Alzheimer's Disease Brain: A Review. Front. Ag. Neurosci. 2018, 10, 42. [CrossRef]

19. Friedland, R.P.; McMillan, J.D.; Kurlawala, Z. What are the molecular mechanisms by which functional bacterial amyloids influence amyloid beta deposition and neuroinflammation in neurodegenerative disorders? Int. J. Mol. Sci. 2020, $21,1652$. [CrossRef]

20. Cummings, J.; Lee, G.; Ritter, A.; Zhong, K. Alzheimer's disease drug development pipeline: 2018. Alzheim. Dem. Trans. Res. Clin. Int. 2018, 4, 195-214. [CrossRef]

21. Beffert, U.; Bertrand, P.; Champagne, D.; Gauthier, S.; Poirier, J. HSV-1 in brain and risk of Alzheimer's disease. Lancet 1998, 351, 1330-1331. [CrossRef]

22. Bhattacharjee, S.; Lukiw, W.J. Alzheimer's disease and the microbiome. Front. Cellul. Neurosci. 2013, 7, 153. [CrossRef] [PubMed]

23. Carter, C. Genetic, Transcriptome, Proteomic, and Epidemiological Evidence for Blood-Brain Barrier Disruption and Polymicrobial Brain Invasion as Determinant Factors in Alzheimer's Disease. J. Alzheim. Dis. Rep. 2017, 1, 125-157. [CrossRef]

24. Friedland, R.P.; Chapman, M.R. The role of microbial amyloid in neurodegeneration. PLoS Pathog. 2017, 13, e1006654. [CrossRef] [PubMed]

25. Pisa, D.; Alonso, R.; Fernández-Fernández, A.; Rábano, A.; Carrasco, L. Polymicrobial Infections In Brain Tissue From Alzheimer's Disease Patients. Sci. Rep. 2017, 7. [CrossRef]

26. Yeh, Y.H.; Gunasekharan, V.; Manuelidis, L. A prokaryotic viral sequence is expressed and conserved in mammalian brain. Proc. Nat. Acad. Sci. USA 2017, 114, 7118-7123. [CrossRef]

27. Dominy, S.S. Porphyromonas gingivalis in Alzheimer's disease brains: Evidence for disease causation and treatment with small-molecule inhibitors. Sci. Adv. 2019, 5, eaau3333. [CrossRef] [PubMed]

28. Tetz, G.; Tetz, V. Bacteriophages as new human viral pathogens. Microorganisms 2018, 6, 54. [CrossRef]

29. Cryan, J.F. The microbiota-gut-brain axis. Physiol. Rev. 2019, 99, 1877-2013. [CrossRef]

30. Marizzoni, M. Short-chain fatty acids and lipopolysaccharide as mediators between gut dysbiosis and amyloid pathology in Alzheimer's disease. J. Alzheimer's Dis. Prepr. 2020, 78, 683-697. [CrossRef]

31. Parker, A.; Fonseca, S.; Carding, S.R. Gut microbes and metabolites as modulators of blood-brain barrier integrity and brain health. Gut Microb. 2020, 11, 135-157. [CrossRef] [PubMed]

32. Tetz, V.; Tetz, G. Bacterial DNA induces the formation of heat-resistant disease-associated proteins in human plasma. Sci. Rep. 2019, 9, 1-10.

33. Tetz, G.; Pinho, M.; Pritzkow, S.; Mendez, N.; Soto, C.; Tetz, V. Bacterial DNA promotes Tau aggregation. Sci. Rep. 2020, 10, 1-11. [CrossRef] [PubMed]

34. Tetz, G.; Brown, S.; Hao, Y.; Tetz, V. Parkinson's disease and bacteriophages as its overlooked contributors. Sci. Rep. 2018, 8 [CrossRef] [PubMed]

35. Tetz, G.; Brown, S.M.; Hao, Y.; Tetz, V. Type 1 diabetes: An association between autoimmunity, the dynamics of gut amyloidproducing E. coli and their phages. Sci. Rep. 2019, 9, 1-11. [CrossRef]

36. Tetz, V.; Tetz, G. Effect of deoxyribonuclease I treatment for dementia in end-stage Alzheimer's disease: A case report. J. Med. Case Rep. 2016, 10, 1-3. [CrossRef]

37. Coureuil, M.; Lécuyer, H.; Bourdoulous, S.; Nassif, X. A journey into the brain: Insight into how bacterial pathogens cross blood-brain barriers. Nat. Rev. Microb. 2017, 15, 149-159. [CrossRef]

38. Dehhaghi, M.; Kazemi Shariat Panahi, H.; Guillemin, G.J. Microorganisms' footprint in neurodegenerative diseases. Front. Cellul. Neurosci. 2018, 12, 466. [CrossRef]

39. Tkáčová, Z. Identification of the proteins of Borrelia garinii interacting with human brain microvascular endothelial cells. Ticks Tick Borne Dis. 2020, 11, 101451. [CrossRef]

40. Van De Haar, H.J.; Burgmans, S.; Jansen, J.F.; Van Osch, M.J.; Van Buchem, M.A.; Muller, M.; Hofman, P.A.; Verhey, F.R.; Backes, W.H. Blood-brain barrier leakage in patients with early Alzheimer disease. Radiology 2016, 281, 527-535. [CrossRef]

41. Li, F.; Hearn, M.; Bennett, L.E. The role of microbial infection in the pathogenesis of Alzheimer's disease and the opportunity for protection by anti-microbial peptides. Crit. Rev. Microbiol. 2021, 5, 1-4.

42. Olsen, I.; Singhrao, S. Can oral infection be a risk factor for Alzheimer's disease? J. Oral Microbiol. 2015, 7, 29143. [CrossRef]

43. Kamer, A.R.; Craig, R.G.; Dasanayake, A.P.; Brys, M.; Glodzik-Sobanska, L.; de Leon, M.J. Inflammation and Alzheimer's disease: Possible role of periodontal diseases. Alzheim. Dem. 2008, 4, 242-250. [CrossRef] [PubMed] 
44. Gade Malmos, K. ThT 101: A primer on the use of thioflavin T to investigate amyloid formation. Amyloid 2017, 24, 1-6. [CrossRef]

45. Salvadores, N.; Shahnawaz, M.; Scarpini, E.; Tagliavini, F.; Soto, C. Detection of Misfolded A $\beta$ Oligomers for Sensitive Biochemical Diagnosis of Alzheimer's Disease. Cell Rep. 2014, 7, 261-268. [CrossRef]

46. Kumar, S.; Walter, J. Phosphorylation of amyloid beta (A $\beta$ ) peptides-A trigger for formation of toxic aggregates in Alzheimer's disease. Aging 2013, 3, 803. [CrossRef] [PubMed]

47. Friedland, R.P. Mechanisms of molecular mimicry involving the microbiota in neurodegeneration. J. Alzheim. Dise. 2015, 45, 349-362. [CrossRef] [PubMed]

48. Vogt, N.M. Gut microbiome alterations in Alzheimer's disease. Sci. Rep. 2017, 7, 1-11. [CrossRef]

49. Alonso, R.; Pisa, D.; Fernández-Fernández, A.M.; Carrasco, L. Infection of fungi and bacteria in brain tissue from elderly persons and patients with Alzheimer's disease. Front. Ag. Neurosci. 2018, 10, 159. [CrossRef]

50. Tetz, V.V.; Tetz, G.V. A new biological definition of life. Biomol. Concepts 2019, 11, 1-6. [CrossRef]

51. Shoemark, D.K.; Allen, S.J. The microbiome and disease: Reviewing the links between the oral microbiome, aging, and Alzheimer's disease. J. Alzheim. Dis. 2013, 43, 725-738. [CrossRef] [PubMed]

52. Weiss, N.; Miller, F.; Cazaubon, S.; Couraud, P.O. The blood-brain barrier in brain homeostasis and neurological diseases. Biochim. Biophys. Acta (BBA) Biomem. 2009, 1788, 842-857. [CrossRef] [PubMed]

53. Hashioka, S. The possible causal link of periodontitis to neuropsychiatric disorders: More than psychosocial mechanisms. Int. J. Molecul. Sci. 2019, 20, 3723. [CrossRef] [PubMed]

54. Chatani, E.; Yamamoto, N. Recent progress on understanding the mechanisms of amyloid nucleation. Biophyss. Rev. 2008, 10, 527-534. [CrossRef] [PubMed]

55. Ikeda, K. presence of intrinsically disordered proteins can inhibit the nucleation phase of amyloid fibril formation of $A \beta$ (1-42) in amino acid sequence independent manner. Sci. Rep. 2020, 10, 1-12. [CrossRef]

56. Kurihara, K.; Tamura, M.; Shohda, K.I.; Toyota, T.; Suzuki, K.; Sugawara, T. Self-reproduction of supramolecular giant vesicles combined with the amplification of encapsulated DNA. Nat. Chem. 2011, 3, 775. [CrossRef]

57. Vilasi, S.; Sarcina, R.; Maritato, R.; De Simone, A.; Irace, G.; Sirangelo, I. Heparin induces harmless fibril formation in amyloidogenic W7FW14F apomyoglobin and amyloid aggregation in wild-type protein in vitro. PLoS ONE 2011, 13, e22076. [CrossRef] [PubMed]

58. Iannuzzi, C.; Irace, G.; Sirangelo, I. The effect of glycosaminoglycans (GAGs) on amyloid aggregation and toxicity. Molecules 2015, 20, 2510-2528. [CrossRef]

59. Bromfield, S.M.; Smith, D.K. Heparin versus DNA: Chiral preferences in polyanion binding to self-assembled multivalent (SAMul) nanostructures. J. Am. Chem. Soc. 2015, 137, 10056-10059. [CrossRef] [PubMed]

60. Glebova, K.; Konorova, I.; Poleshchuk, V.; Baidakova, G.; Veiko, N. Properties of Extracellular DNA from the Cerebrospinal Fluid and Blood Plasma during Parkinson's Disease. Bullet. Exp. Biol. Med. 2014, 156, 826-828. [CrossRef] [PubMed]

61. Connolly, I. A pilot study on the use of cerebrospinal fluid cell-free DNA in intramedullary spinal ependymoma. J. Neuro-Oncol. 2017, 135, 29-36. [CrossRef] [PubMed]

62. Bennett, J.; Keeney, P.; Brohawn, D. RNA Sequencing Reveals Small and Variable Contributions of Infectious Agents to Transcriptomes of Postmortem Nervous Tissues From Amyotrophic Lateral Sclerosis, Alzheimer's Disease and Parkinson's Disease Subjects, and Increased Expression of Genes From Disease-Activated Microglia. Front. Neurosci. 2019, 13, 235. [PubMed]

63. Crespo, R.; Villar-Alvarez, E.; Taboada, P.; Rocha, F.A.; Damas, A.M.; Martins, P.M. What can the kinetics of amyloid fibril formation tell about off-pathway aggregation? J. Biol. Chem. 2016, 291, 2018-2032. [CrossRef]

64. Walsh, D.M. Amyloid $\beta$-protein fibrillogenesis: Structure and biological activity of protofibrillar intermediates. J. Biol. Chem. 1999, 274, 25945-25952. [CrossRef] [PubMed]

65. Habicht, G. Directed selection of a conformational antibody domain that prevents mature amyloid fibril formation by stabilizing A $\beta$ protofibrils. Proc. Nat. Acad. Sci. USA 2007, 104, 19232-19237. [CrossRef]

66. Peng, C. Cellular milieu imparts distinct pathological $\alpha$-synuclein strains in $\alpha$-synucleinopathies. Nature 2018, 557, 558-563. [CrossRef]

67. Ferreira, N. Multiple system atrophy-associated oligodendroglial protein p25 $\alpha$ stimulates formation of novel $\alpha$-synuclein strain with enhanced neurodegenerative potential. Acta Neuropathol. 2021, 12, 1-29.

68. Cohen, M.; Appleby, B.; Safar, J.G. Distinct prion-like strains of amyloid beta implicated in phenotypic diversity of Alzheimer's disease. Prion 2016, 10, 9-17. [CrossRef]

69. Pietronigro, E.C.; Della Bianca, V.; Zenaro, E.; Constantin, G. NETosis in Alzheimer's disease. Front. Immunol. 2017, 8, 211. [CrossRef]

70. Cerovic, M.; Forloni, G.; Balducci, C. Neuroinflammation and the gut microbiota: Possible alternative therapeutic targets to counteract Alzheimer's disease? Front. Aging Neurosci. 2019, 11, 284. [CrossRef]

71. Poole, S.; Singhrao, S.; Kesavalu, L.; Curtis, M.; Crean, S. Determining the Presence of Periodontopathic Virulence Factors in Short-Term Postmortem Alzheimer's Disease Brain Tissue. J. Alzheim. Disease 2013, 36, 665-677. [CrossRef]

72. Tohidpour, A. Neuroinflammation and infection: Molecular mechanisms associated with dysfunction of neurovascular unit. Front. Cellul. Infect. Microbiol. 2017, 7, 276. [CrossRef]

73. Guzman-Martinez, L.; Maccioni, R.B.; Andrade, V.; Navarrete, L.P.; Pastor, M.G.; Ramos-Escobar, N. Neuroinflammation as a common feature of neurodegenerative disorders. Front. Pharmacol. 2019, 10, 1008. [CrossRef] [PubMed]

74. Ismail, R. The relationships between neuroinflammation, beta-amyloid and tau deposition in Alzheimer's disease: A longitudinal PET study. J. Neuroinf. 2020, 17, 1-11. [CrossRef] [PubMed] 
75. Chen, S.G. Exposure to the functional bacterial amyloid protein curli enhances alpha-synuclein aggregation in aged Fischer 344 rats and Caenorhabditis elegans. Sci. Rep. 2016, 6, 1-10. [CrossRef] [PubMed]

76. Van Den Berge, N. Evidence for bidirectional and trans-synaptic parasympathetic and sympathetic propagation of alpha-synuclein in rats. Acta Neuropathol. 2019, 138, 535-550. [CrossRef]

77. Kim, S. Transneuronal propagation of pathologic $\alpha$-synuclein from the gut to the brain models Parkinson's disease. Neuron 2019, 103, 627-641. [CrossRef] [PubMed]

78. Sun, Y.; Sommerville, N.R.; Liu, J.Y.; Ngan, M.P.; Poon, D.; Ponomarev, E.D.; Lu, Z.; Kung, J.S.; Rudd, J.A. Intra-gastrointestinal amyloid- $\beta 1-42$ oligomers perturb enteric function and induce Alzheimer's disease pathology. J. Physiol. 2020, 598, 4209-4223. [CrossRef] [PubMed]

79. Ferreira, N. Trans-synaptic spreading of alpha-synuclein pathology through sensory afferents leads to sensory nerve degeneration and neuropathic pain. Acta Neuropathol. Commun. 2021, 9, 1-17. [CrossRef]

80. Braak, H.; Rub, U.; Gai, W.; Del Tredici, K. Idiopathic Parkinson's disease: Possible routes by which vulnerable neuronal types may be subject to neuroinvasion by an unknown pathogen. J. Neural Transm. 2003, 110, 517-536. [CrossRef] 